\begin{tabular}{lllll}
\hline LEK. SIROV. & God.XXXVI & Broj 36 & Str. 37 - 46 & Beograd 2016. \\
LEK. SIROV. & Vol.XXXVI & No. 36 & Pp. 37-46 & Belgrade 2016. \\
\hline
\end{tabular}

Originalni rad - Original paper

Manuscript received: 14.9 .2016$.

UDC: $615.322: 582.284 .3$

COBISS.SR-ID 228491020

Accepted for publication: 12.10.2016.

\title{
ANTIBACTERIAL AND ANTIFUNGAL POTENTIAL OF WILD BASIDIOMYCETE MUSHROOM GANODERMA APPLANATUM
}

\author{
Anita S. Klaus ${ }^{1}$, Maja S. Kozarski ${ }^{2}$, Jovana Đ. Vunduk ${ }^{1}$, Predrag M. Petrović룰, \\ Miomir P. Nikšić ${ }^{1}$ \\ ${ }^{1}$ Department for Industrial Microbiology, Faculty of Agriculture, University of Belgrade, \\ Nemanjina 6, 11080 Belgrade, Serbia \\ ${ }^{2}$ Department for Chemistry and Biochemistry, Faculty of Agriculture, University of \\ Belgrade, Nemanjina 6, 11080 Belgrade, Serbia \\ ${ }^{3}$ Department of Chemical Engineering, Faculty of Technology and Metallurgy, University \\ of Belgrade, Karnegijeva 4, 11060 Belgrade, Serbia
}

\begin{abstract}
Hot water extract (AN), partially purified polysaccharides (AP) and hot alkali extract (ANa) obtained from wild mushroom $G$. applanatum were examined for their antibacterial and antifungal activity. Five Gram negative (Proteus hauseri, Escherichia coli O157:H7, Salmonella Enteritidis, Shigella sonnei, Yersinia enterocolitica), five Gram positive (Listeria monocytogenes, Staphylococcus aureus, Bacillus cereus, Geobacillus stearothermophyllus, Enterococcus faecalis) bacterial strains, as well as two fungal strains (Candida albicans and Cryptococcus neoformans), all belonging to the American Type Culture Collection (ATCC), were tested by broth microdilution assay. In general, Gram-positive bacteria were more sensitive in the presence of tested extracts than Gram-negative bacterial species. Almost all tested extracts demonstrated a high microbistatic potential, and in most cases the microbicidal effect also has been reached. The best antibacterial effect of hot water alkali extract, $\mathrm{ANa}$, was observed in the case of E. faecalis (MIC $0.039 \mathrm{mg} / \mathrm{mL}$, MBC $1.25 \mathrm{mg} / \mathrm{mL}$ ), while the same extract was the most effective antifungal agent towards $C$. neoformans (MIC $0.078 \mathrm{mg} / \mathrm{mL}$, MFC $2.5 \mathrm{mg} / \mathrm{mL}$ ). This research indicates possibility to use selected extracts, obtained from the mushroom $G$. applanatum, in order to
\end{abstract}


prevent the development of some pathogenic microorganisms and food spoilage.

Ključne reči: Ganoderma applanatum, mushroom extract, bactericidal, bacteriostatic, fungicidal, fungistatic

\section{INTRODUCTION}

Ganoderma applanatum (Pers.) Pat., also known as artist's conk, artist's bracket or bear bread, is a very common, perennial, woody shelf fungus, widely distributed throughout the world, mostly being found in temperate and tropical zones. It usually appears individually or in clusters, on the sides of hardwood trees, which is their specific niche. Growing on logs, stumps or dead or dying trees, this basidiomycete is very important decomposer of wood material, contributing to the mineralization of organic waste.

Among numerous mushrooms, woody polyporaceae $G$. applanatum is unique in being consumed for its pharmaceutical value rather than as a food. It was used in traditional medicine of the Far East for treating many disorders in the body. Modern scientific research, which was carried out very intensively in recent decades, confirms a number of positive effects of this valuable mushroom on human health. A variety of bioactive compounds, such as polysaccharides, polyphenols, triterpenoids, amino acids, polypeptides are present in fruiting bodies and mycelium of $G$. applanatum. These active ingredients contribute to the biological activities, such as antitumor and immunomodulating $[1,2]$ or antiviral properties [3]. This, highly valuable mushroom also contain antioxidant compounds that have important ability to trap free radicals and thus inhibit the oxidative mechanisms which lead to the degenerative diseases [4, 5]. $G$. applanatum possesses liver protective activity by decreasing reactive oxygen species; its terpenes renewed activities of antioxidant enzymes and suppressed the inflammatory response [6]. A possible effectiveness of this mushroom as an antiobesity agent because of the ability to inhibit the differentiation of preadipocytes into mature adipocytes, by reducing triglyceride accumulation, is proven [7].

During recent years many investigations confirmed antimicrobial activity of numerous edible and inedible mushrooms extracts $[8,9,10,11,12,13]$. This could be of great importance, considering that there are a number of microorganisms which are able to cause different diseases, spoil food, cosmetic and pharmaceutical products whose use might cause intoxication. A common way to fight against microorganisms is the use of the appropriate antibiotics, but there are also significant problems caused by their long-term use, since the microorganisms 
become resistant to them. Additionally, there are many side effects, especially during prolonged and improper use of antibiotics. Therefore, the search for new antimicrobial agents without adverse effects, such as various herbs and mushrooms, is of major importance. Regarding these facts, it would be very suitable to develop naturally occurring product which would be able to reduce or completely interrupt the proliferation of microorganisms.

The aim of this investigation was to determine the in vitro antibacterial and antifungal effect of hot water extract (AN), partially purified polysaccharides (AP) and hot alkali extract (ANa) obtained from wild mushroom G. applanatum.

\section{MATERIAL AND METHODS}

\section{Sample collection}

Fresh wild-growing fruiting bodies of mushroom G. applanatum were collected from the side of wild beech (Fagus silvatica L.) trunk, from the forest park Košutnjak, Belgrade, Republic of Serbia, in the autumn 2014. Carpophores were identified by authors from an examination of macro- and micromorphology, in comparison to standard descriptions in the monographs and taxonomic treatments. Carpophores were brush-cleaned, air-dried at $40^{\circ} \mathrm{C}$ to constant mass and ground into fine particles, and stored in the dark prior to analysis. The mycelial culture which was stored at $4^{\circ} \mathrm{C}$ in the mushrooms culture collection, as well as representative voucher specimens were deposited at the herbarium of the Department for Industrial Microbiology (Faculty of Agriculture, University of Belgrade).

\section{Preparation of extracts}

$\mathrm{AN}, \mathrm{AP}$ and ANa were obtained from wild mushroom G. applanatum, according to previously described procedures [14].

\section{Antibacterial and antifungal activity testings with broth microdilution} method

Five Gram-positive (Listeria monocytogenes, Staphylococcus aureus, Bacillus cereus Geobacillus stearothermophilus, Enterococcus faecalis) and five Gram-negative bacterial species (Proteus hauseri, Escherichia coli O157:H7, Salmonella enteritidis, Shigella sonnei, Yersinia enterocolitica), were challenged in this study to ascertain the antibacterial properties of AN, AP and ANa from $G$. applanatum. Selected species of bacteria originate from ATCC (American Type Culture Collection, Rockville, Maryland). These microorganisms were chosen for the bioassay as well known food spoilage and pathogenic microorganisms. 
Working concentrations of bacteria, as well as stock solutions and working solutions were prepared according to previously described method [9].

Two yeasts' ATCC strains (Candida albicans, Cryptococcus neoformans) were also used to determine antifungal potential of $G$. applanatum extracts. These pathogenic yaests were maintained on malt agar and the same media was used to confirm the absence of contamination and the validity of the inocula. Before testing, each yeast species was recovered by sub-culturing in the malt broth, aerobically, for $24 \mathrm{~h}$, at $37^{\circ} \mathrm{C}$. Working concentrations of yeasts, as well as stock solutions and working solutions were prepared in the same manner as for bacteria.

Broth microdilution method employed to determine minimum inhibitory (MIC) and minimum bactericidal concentrations (MBC) or minimum fungicidal concentrations (MFC) is described previously $[9,15]$. Concentrations of mushroom extracts ranged from 0.0097 to $20.0 \mathrm{mg} / \mathrm{mL}$. Amoxicillin trihydrate was used as a positive controle for bacterial strains, while fluconazole was used as a positive controle for yeasts strains.

\section{Statistical analysis}

All measurements were done in triplicate. The experimental data were subjected to one-way analysis of variance (ANOVA) and Fisher's LSD was calculated to detect significant difference $(p \leq 0.05)$ between the mean values.

\section{RESULTS AND DISCUSSION}

The broth microdilution method as a rapid quantitative determination of MIC, based on the color change caused by the enzymatic activity of viable bacteria, was applied. Well defined endpoints appeared as the results of the metabolic activity of bacteria, i.e. TTC reduction (Table 1).

In the presence of G.applanatum extracts, the growth inhibition of almost all tested microorganisms was observed. Gram-negative bacteria appeared to be more resistant than Gram-positive bacteria; exceptions were $S$. enteretidis (MIC $0.625 \mathrm{mg} / \mathrm{mL}, \mathrm{MBC} 10.0 \mathrm{mg} / \mathrm{mL}$ ) and $Y$. enterocolitica (MIC $0.3125 \mathrm{mg} / \mathrm{mL}$, $\mathrm{MBC} 10.0 \mathrm{mg} / \mathrm{mL}$ ) after exposure to ANa. Only in these two cases the influence of $\mathrm{ANa}$ resulted in $\mathrm{MBC}$ achieving.

In general, Gram-positive bacteria were more susceptible than Gramnegative bacterial species. Among tested extract, ANa is shown to be the most effective against Gram-positive bacteria (MIC 0.039-0.625 mg/mL; MBC 1.25$10.0 \mathrm{mg} / \mathrm{mL}$ ); slightly weaker activity was observed in AP (MIC 0.156-1.25 $\mathrm{mg} / \mathrm{ml}$; MBC 2.5-10.0 mg/mL), while AN (MBC 0.3125-5.0 mg/mL; MBC 5.0$20.0 \mathrm{mg} / \mathrm{mL}$ ) was the least active. 
Table 1. Antimicrobial activity of $\mathrm{AN}, \mathrm{AP}$ and $\mathrm{ANa}$, and standard antibiotics amoxicillin (AMX) and fluconazole (FLU), expressed as MIC (mg/mL), MBC $(\mathrm{mg} / \mathrm{mL})$ and MFC $(\mathrm{mg} / \mathrm{mL})$, determined by the broth microdilution method. Data are expressed as mean of the three replicates. Standard deviations are not shown, as the results for all replications were equal.

Tabela 1. Antimikrobna aktivnost ekstrakata AN, AP i ANa, i standardnih antibiotika amoksicilina (AMX) i flukonazola (FLU), izražena kao MIC (mg/mL), MBC $(\mathrm{mg} / \mathrm{mL})$ i MFC $(\mathrm{mg} / \mathrm{mL})$, određena mikrodilucionom metodom u bujonu. Podaci su izraženi kao srednje vrednosti tri ponavljanja. Standardne devijacije nisu prikazane jer su rezultati svih ponavljanja jednaki.

\begin{tabular}{|c|c|c|c|c|c|c|c|}
\hline Microorganism & Source & & $\mathbf{A N}$ & AP & ANa & AMX & FLU \\
\hline \multirow{2}{*}{ Proteus hauseri } & ATCC & MIC & $10.0^{\mathrm{a} 1}$ & $-^{2}$ & $1.25^{\mathrm{b}}$ & $0.0027^{\mathrm{c}}$ & $\mathrm{nd}^{3}$ \\
\hline & 13315 & $\mathrm{MBC}$ & - & - & - & 0.0108 & nd \\
\hline \multirow{4}{*}{$\begin{array}{l}\text { Escherichia coli } \\
\text { O157:H7 } \\
\text { Salmonella } \\
\text { enteritidis }\end{array}$} & ATCC & MIC & $5.0^{\mathrm{a}}$ & - & $1.25^{\mathrm{b}}$ & $0.0054^{\mathrm{c}}$ & nd \\
\hline & 35150 & MBC & - & - & - & 0.0217 & nd \\
\hline & ATCC & MIC & $2.5^{\mathrm{b}}$ & $5.0^{\mathrm{a}}$ & $0.625^{\mathrm{c}}$ & $0.0007^{\mathrm{d}}$ & nd \\
\hline & 13076 & $\mathrm{MBC}$ & - & - & $10.0^{\mathrm{a}}$ & $0.0027^{\mathrm{b}}$ & nd \\
\hline \multirow{2}{*}{ Shigella sonei } & ATCC & MIC & $2.5^{\mathrm{a}}$ & $2.5^{\mathrm{a}}$ & $1.25^{\mathrm{b}}$ & $0.0054^{\mathrm{c}}$ & nd \\
\hline & 29930 & MBC & - & - & - & 0.0108 & nd \\
\hline \multirow{2}{*}{$\begin{array}{l}\text { Yersinia } \\
\text { enterocolitica }\end{array}$} & ATCC & MIC & $1.25^{\mathrm{a}}$ & $1.25^{\mathrm{a}}$ & $0.3125^{\mathrm{b}}$ & 0.0108 & nd \\
\hline & 27729 & $\mathrm{MBC}$ & - & - & $10.0^{\mathrm{a}}$ & $0.0108^{\mathrm{b}}$ & nd \\
\hline Listeria & ATCC & MIC & $2.5^{\mathrm{a}}$ & $1.25^{\mathrm{b}}$ & $0.156^{\mathrm{c}}$ & $0.0003^{\mathrm{d}}$ & nd \\
\hline monocytogenes & 19115 & $\mathrm{MBC}$ & $20.0^{\mathrm{a}}$ & $10.0^{\mathrm{b}}$ & $5.0^{\mathrm{c}}$ & $0.0027^{\mathrm{d}}$ & nd \\
\hline \multirow{2}{*}{$\begin{array}{l}\text { Staphylococcus } \\
\text { aureus }\end{array}$} & ATCC & MIC & $2.5^{\mathrm{a}}$ & $1.25^{\mathrm{b}}$ & $0.3125^{\mathrm{c}}$ & $0.0002^{\mathrm{d}}$ & nd \\
\hline & 6538 & $\mathrm{MBC}$ & $20.0^{\mathrm{a}}$ & $10.0^{\mathrm{b}}$ & $10.0^{\mathrm{b}}$ & $0.0014^{\mathrm{c}}$ & nd \\
\hline Bacillus cereus & ATCC & MIC & $2.5^{\mathrm{a}}$ & $1.25^{\mathrm{b}}$ & $0.625^{\mathrm{c}}$ & $0.0003^{\mathrm{d}}$ & nd \\
\hline ATCC & 10876 & MBC & $20.0^{\mathrm{a}}$ & $10.0^{\mathrm{b}}$ & $10.0^{\mathrm{b}}$ & $0.0054^{\mathrm{c}}$ & nd \\
\hline \multirow{2}{*}{$\begin{array}{l}\text { Geobacillus } \\
\text { stearothermophylus }\end{array}$} & ATCC & MIC & $5.0^{\mathrm{a}}$ & $0.625^{\mathrm{b}}$ & $0.3125^{\mathrm{c}}$ & $0.0003^{\mathrm{d}}$ & nd \\
\hline & 7953 & $\mathrm{MBC}$ & $20.0^{\mathrm{a}}$ & $5.0^{\mathrm{b}}$ & $2.5^{\mathrm{c}}$ & $0.0027^{\mathrm{d}}$ & nd \\
\hline \multirow{2}{*}{$\begin{array}{l}\text { Enterococcus } \\
\text { faecalis }\end{array}$} & ATCC & MIC & $0.3125^{\mathrm{a}}$ & $0.156^{\mathrm{b}}$ & $0.039^{c}$ & $0.0003^{\mathrm{d}}$ & nd \\
\hline & 29212 & MBC & $5.0^{\mathrm{a}}$ & $2.5^{\mathrm{b}}$ & $1.25^{\mathrm{c}}$ & $0.0027^{\mathrm{d}}$ & nd \\
\hline \multirow{2}{*}{ Candida albicans } & ATCC & MIC & $1.25^{\mathrm{a}}$ & $1.25^{\mathrm{a}}$ & $0.156^{b}$ & nd & $0.0125^{\mathrm{c}}$ \\
\hline & 24443 & MFC & $20.0^{\mathrm{a}}$ & $10.0^{\mathrm{b}}$ & $10.0^{\mathrm{b}}$ & nd & $0.05^{\mathrm{c}}$ \\
\hline \multirow{2}{*}{$\begin{array}{l}\text { Cryptococcus } \\
\text { neoformans }\end{array}$} & ATCC & MIC & $1.25^{\mathrm{a}}$ & $0.625^{\mathrm{b}}$ & $0.078^{\mathrm{c}}$ & nd & $0.0063^{\mathrm{d}}$ \\
\hline & 76484 & MFC & $10.0^{\mathrm{a}}$ & $5.0^{\mathrm{b}}$ & $2.5^{\mathrm{c}}$ & nd & $0.0063^{\mathrm{d}}$ \\
\hline
\end{tabular}

The hot alkali extract, ANa, also was the most effective against fungal strains C. neoformans and C. albicans (MIC $-0.078 \mathrm{mg} / \mathrm{mL}$ and $0.156 \mathrm{mg} / \mathrm{mL}$, 
MBC $-2.5 \mathrm{mg} / \mathrm{mL}$, and $10.0 \mathrm{mg} / \mathrm{mL}$, respectively). The other two extracts, AP and $\mathrm{AN}$, exibited antifungal activity to a somewhat lesser extent (MIC $-0.625-1.25$ $\mathrm{mg} / \mathrm{mL}$; MFC - 5.0-20.0 mg/mL).

This investigation revealed a great antimicrobial potential of different extracts obtained from $G$. applanatum. Of particular interest is extract ANa which proved to be a highly effective against most of tested microorganisms, especially $E$. faecalis and $C$. neoformans. These microorganisms could be triggers for very serious health disorders. Although E. faecalis is normal gut commensals, under suitable circumstances it can cause urinary tract or wound infections, endocarditis and bacteremia. E. faecalis is responsible for approximately 110.000 cases of urinary tract infections yarly [16]. Further, C. neoformans, an encapsulated yeast is a major cause of illness in persons with a weakened immune system (e.g. HIV patients), with an estimated 1.000 .000 cases of cryptococcal meningitis occuring worldwide each year [17].

In recent years, several reports concerning antimicrobial power of different G. applanatum extracts have been published $[18,19,20,21]$. These investigations suggest that the antimicrobial effect depend on the method of extraction, i.e. on the type of the extract, microorganism strain, exposure time. Karaman et al., 2009 reported that $60 \%$ methanol and 55\% chloroform extracts (among others was also G. applanatum) reached a significant antibacterial activity against one or more targeted bacteria [22]. Regarding the fact that macrofungi are commonly collected either randomly or by locals in forests, it would be necessary to perform initial screening for possible antimicrobial activities by using crude aqueous or alcohol extractions. Proper selection of the extraction procedure directly determines the antimicrobial activity of the extract [23].

G. applanatum is one of the medicinally important mushroom which is used for the production of mushroom-based health care commercial biotechproducts with preventive and curative effects. Nowadays, these kinds of products are available and highly sought in the world market. They could be find in dried forms as healthy food ("nutraceuticals"), as well as functional food additives ("pharmaceuticals" or "nutriceuticals"). Due to synergistic action of present bioactive molecules, the majority of mushroom products possess beneficial health effects and could be used without adverse effects [24].

\section{CONCLUSIONS}

Our investigation showed that $G$. applanatum is extremely valuable mushroom, with strong antimicrobial potential. Depending on the method of extraction it is possible to obtain different kinds of extracts that could act as microbistatic or microbicidal agents against certain species and strains of 
microorganisms. The most prominent extract found to be ANa, obtained in very intense chemical processes of degradation, transformation and formation of new molecules, all of which did not diminished its biological activity. On the contrary, hot alkali extract ANa, exhibited microbicidal effect on the majority of tested strains. Since the food can be contaminated by various pathogenic and spoiling microorganisms, supplementation with targeted $G$. applanatum extracts could contribute to the reduction of food poisoning.

\section{ACKNOWLEDGEMENT}

This investigation was financially supported by the Ministry of Science and Technological Development of the Republic of Serbia, projects III 46001 and III 46010.

\section{REFERENCES}

1. J.T. Jeong, B.K. Yang, S.C. Jeong, S.M. Kim, C.H. Song (2008): Ganoderma applanatum: a promising mushroom for antitumour and immunomoduling activity, Phytotherapy research, Vol. 22, 614-619.

2. J. Smith, S. Rowan, R. Sullivan (2002): Medicinal Mushrooms: Their therapeutic properties and current medical usage with special emphasis on cancer treatments, University of Strathclyde/Cancer Research, UK.

3. M. Sofni, S.M. Chairul, Y. Hayashi (1994): Lanostanoid triterpenes from Ganoderma applanatum, Phytochemistry, Vol. 35, No. 5. 1305-1308.

4. M. Kozarski, A. Klaus, M. Nikšić, M. Vrvić, N. Todorović, D. Jakovljević, L.J.L.D. Van Griensven (2012): Antioxidative activities and chemical characterization of polysaccharide extracts from the widely used mushrooms Ganoderma applanatum, Ganoderma lucidum, Lentinus edodes and Trametes versicolor, Journal of Food Composition and Analysis, Vol 26, 144-153.

5. K. Acharya, P. Yonzone, M. Rai, R. Acharya (2005): Antioxidant and nitric oxide synthase activation properties of Ganoderma applanatum, Indian Journal of Experimental Biology, Vol.43, 926-929.

6. J.Q. Ma, C.M. Liu, Z.H. Qin, J.H. Jiang, Y.Z. Sun (2011): Ganoderma applanatum Terpenes Protect Mouse Liver against Benzo $(\alpha)$ pyren-induced Oxidative Stress and Inflammation, Environmental Toxicology and Pharmacology, Vol. 31, No. 3, 460-468.

7. J.E. Kim, S.J. Park, M.H. Yu, S.P. Lee (2014): Effect of Ganoderma applanatum mycelium extract on the inhibition of adipogenesis in 3T3-L1 adipocytes, Journal of Medicinal Food, Vol. 17, No. 10, 1086-1094. 
8. 8. P. Petrović, J. Vunduk, A. Klaus, M. Kozarski, M. Nikšić, Ž. Žižak, N. Vuković, G. Šekularac, S. Drmanić, B. Bugarski (2016): Biological potential of puffballs: A comparative analysis, Journal of Functional Foods, Vol. 21, 3649.

9. A. Klaus, M. Kozarski, J. Vunduk, N. Todorovic, D. Jakovljevic, Z. Zizak, V. Pavlovic, S. Levic, M. Niksic, L.J.L.D Van Griensven (2015): Biological potential of extracts of the wild edible Basidiomycete mushroom Grifola frondosa, Food Research International, Vol. 67, 272-283.

10. J. Vunduk, A. Klaus, M. Kozarski, P. Petrović, Ž. Žižak, M. Nikšić., L.J.L.D. Van Griensven (2015): Did the Iceman Know Better? Screening of the Medicinal Properties of the Birch Polypore Medicinal Mushroom, Piptoporus betulinus (Higher Basidiomycetes), International Journal of Medicinal Mushrooms, Vol. 17, No. 12, 1113-1125.

11. M. Kozarski, A. Klaus, Z. Zizak, M. Niksic, D. Jakovljevic, M. Vrvic, L.J.L.D. Van Griensven (2015): Nutraceutical properties of the methanolic extract of edible mushroom Cantharellus cibarius (Fries): primary mechanisms, Food \& Function, Vol. 6, 1875-1886.

12. H. Pushpa, M. Anand, P. Kasimaiah, J.V.S.P. Penugonda (2013): Evaluation of antimicrobial activity of some of the selected basidiomycetous fungi, International Journal of Pharma and Bio Sciences, Vol. 4, No. 4, 964-971.

13. M.J. Alves, I.C. Ferreira, J. Dias, V. Teixeira, A. Martins, M. Pintado (2012): A review on antimicrobial activity of mushroom (Basidiomycetes) extracts and isolated compounds, Planta medica, Vol. 78, No. 16, 1707-1718.

14. A. Klaus, M. Kozarski, M. Nikšić, D. Jakovljević, N. Todorović, L.J.L.D. Van Griensven (2011): Antioxidative activities and chemical characterization of polysaccharides extracted from the basidiomycete Schizophyllum commune, LWT-Food Science and Technology, Vol. 44, 2005-2011.

15. CLSI- Clinical and Laboratory Standards Institute (2005): Performance standards for antimicrobial susceptibility testing: $15^{\text {th }}$ informational supplement, CLSI document M100-S15, Wayne, PA, USA.

16. A.L. Kau, S.M. Martin, W. Lyon, E. Hayes, M.G. Caparon, S.J. Hultgren (2005): Enterococcus faecalis Tropism for the Kidneys in the Urinary Tract of C57BL/6J Mice, Infection and Immunity, Vol. 73, No. 4, 2461-2468.

17. B.J. Park, K.A. Wannemuehler, B.J. Marston, N. Govender, P.G. Pappas, T.M. Chiller (2009): Estimation of the current global burden of cryptococcal meningitis among persons living with HIV/AIDS, Aids, Vol 23, No. 4, 525530 .

18. F.E. Oviasogie, E.O. Akpaja, K.C. Gbona, E.A. Akonoafua (2015): Antimicrobial properties of Ganoderma applanatum (Pers.) Pat. from Benin city, Nigeria, Nigerian Journal of Agriculture, Food and Environment, Vol. 11, No. 3, 65-69. 
19. M. Osińska-Jaroszuk, M. Jaszek, M. Mizerska-Dudka, A. Błachowicz, T.P. Rejczak, G. Janusz, J. Wydrych, J. Polak, A. Jarosz-Wilkołazka, M., KandeferSzerszeń (2014): Exopolysaccharide from Ganoderma applanatum as a Promising Bioactive Compound with Cytostatic and Antibacterial Properties, BioMed Research International, Vol. 2014, 1-10.

20. T.M. Muhsin, A.H.A. Al-Duboon, T. Kawther, K.T. Khalaf (2011): Bioactive Compounds from a Polypore Fungus Ganoderma applanatum (Pers. ex Wallr.) Pat, Jordan Journal of Biological Sciences, Vol. 4, No. 4, 205-212.

21. B.J. Akinyele, J.O. Obameso, M.K. Oladunmoye (2011): Phytochemical screening and antimicrobial potentials of three indigenous wild Ganodema mushroom from Ondo State, Nigeria, Nigerian Journal of Microbiology, Vol 24, No 1.

22. M. Karaman, N. Mimica-Dukić, P. Knežević, Z. Svirčev, M. Matavulj (2009): Antibacterial properties of selected lignicolous mushrooms and fungi from northern Serbia, International Journal of Medicinal Mushrooms, Vol.11, No.3, 269-279.

23. M. Karaman, M. Matavulj, Lj. Janjić (2012): Antibacterial Agents from Lignicolous Macrofungi, 361-386.

24. S. M. Badaylan (2014): Potential of mushroom bioactive moleciles to develop healthcare biotech products, Proceedings of the $8^{\text {th }}$ International Conference on Mushroom Biology and Mushroom Products (ICMBMP8), 373-378. 


\section{ANTIBAKTERIJSKI I ANTIFUNGALNI POTENCIJAL GLJIVE GANODERMA APPLANATUM BAZIDIOMICETE IZ PRIRODE}

\section{Anita S. Klaus ${ }^{1}$, Maja S. Kozarski ${ }^{2}$, Jovana Đ. Vunduk ${ }^{1}$, Predrag M. Petrović ${ }^{3}$, Miomir P. Nikšić ${ }^{1}$}

\footnotetext{
${ }^{1}$ Katedra za tehnološku mikrobiologiju, Poljoprivredni fakultet, Univerzitet u Beogradu, Nemanjina 6, 11080 Beograd, Srbija

${ }^{2}$ Katedra za hemiju i biohemiju, Poljoprivredni fakultet, Unverzitet u Beogradu, Nemanjina 6, 11080 Beograd, Srbija

${ }^{3}$ Katedra za hemijsko inženjerstvo, Tehnološko-metalurški fakultet, Univerzitet u Beogradu, Karnegijeva 4, 11060 Beograd, Srbija
}

\section{REZIME}

Ispitivana je antibakterijska $\mathrm{i}$ antifungalna aktivnost vrelog vodenog ekstrakta (AN), parcijalno prečišćenog polisaharidnog ekstrakta (AP) i vrelog alkalnog ekstrakta, dobijenih iz G. applanatum, gljive iz prirode. Pet Gram negativnih (Proteus hauseri, Escherichia coli O157:H7, Salmonella Enteritidis, Shigella sonnei, Yersinia enterocolitica), pet Gram pozitivnih (Listeria monocytogenes, Staphylococcus aureus, Bacillus cereus, Geobacillus stearothermophyllus, Enterococcus faecalis) bakterijskih vrsta, kao i dva soja gljiva (Candida albicans and Cryptococcus neoformans), od kojih svi pripadaju Američkoj tipskoj kolekciji kultura (ATCC), testirani su mikrodilucionom metodom u bujonu. Generelno, Gram pozitivne bakterije su bile mnogo osetljivije u prisustvu testiranih ekstrakata nego Gram negativne bakterijske vrste. Skoro svi testirani ekstrakti pokazali su visok mikrobistatički potencijal, a u najvećem broju slučajeva dostignut je i mikrobicidni efekat. Najbolji antibakterijski efekat vrelog alkalnog ekstrakta, ANa, uočen je u slučaju E. faecalis (MIC $0.039 \mathrm{mg} / \mathrm{mL}, \mathrm{MBC}$ $1.25 \mathrm{mg} / \mathrm{mL}$ ), dok je ovaj ekstrakt bio i najefikasniji antifungalni agens prema $C$. neoformans (MIC $0.078 \mathrm{mg} / \mathrm{mL}$, MFC $2.5 \mathrm{mg} / \mathrm{mL}$ ). Ovo istraživanje ukazuje na mogućnost korišćenja odabranih ekstrakata dobijenih iz gljive G. applanatum u cilju prevencije razvoja nekih patogenih mikroorganizama i kvarenja hrane.

Key words: Ganoderma applanatum, ekstrakti gljiva, baktericidno, bakteriostatičko, fungicidno, fungistatičko 